\title{
VALUE CHAIN ANALYSIS OF ADVENTURE TOURISM: A CASE STUDY OF AJARA AUTONOMOUS REPUBLIC (GEORGIA)
}

\author{
Nargiz Phalavandishvili ${ }^{1}$, Business Administration Doctor, Assist., Prof. ; \\ Natalia Robitashvili², Business Administration Doctor, Assoc. Prof.; \\ Ekaterine Bakhtadze ${ }^{3}$, PhD of Economics, Assoc. Prof. \\ 1, 2, 3Batumi Shota Rustaveli State University
}

\begin{abstract}
Ajara Autonomous Republic, both within the country and in the world tourist market, has always been positioned as a maritime tourist destination. However, over recent years diversification of tourist products and appealing new market segments have become one of the main priorities of the tourism development strategy of Ajara Autonomous Republic. As a result, the government is creating an appropriate tourist infrastructure, especially in rural areas to support developing such tourist products as adventure and eco-tourism. Adventure tourism can deliver significant benefits at the local level and it is a developing segment in Ajara. Creating adventure tourism products requires integration of various interdependent services. A tourism value chain is defined as a system that describes the cooperation of private and state sectors in providing resources, which creates costs and adds value through various processes and delivers final products to visitors. The purpose of the research was to determine weak links in the value chain and creating a comprehensive value chain model to form the competitive adventure tourism product. The research involved all actors, which operate in the tourism sector. Based on the results of the survey, in the value chain, the food link turned out to be the weakest, whereas the accommodation with the highest share was distinguished in the visitor spending structure. Overall, the cost of the adventure tour will be affordable for both international and domestic tourists. At this stage, government support and participation are crucial in the formation of adventure tourism infrastructure. Through using the case study and qualitative research methods, we tried to identify challenges to the growth of adventure tourism in Ajara and developed recommendations to overcome these challenges.
\end{abstract}

Keywords: adventure tourism, case study, value chain analysis.

JEL code: $M 2$

\section{Introduction}

Prior to the 2020 pandemic period caused by COVID-19, a growing trend of visitors was observed in Georgia, including the Autonomous Republic of Ajara. According to the World Bank report, "Georgia has become a competitive tourist destination in recent years" (Forbes Georgia, 2018), Ajara hosted an average of 2 million visitors each year, and the number of tourists in 2019 exceeded one million. Since the Soviet era, Adjara has been considered one of the most attractive locations for maritime tourism. Today, gambling tourism is added to the seaside vacation, which mainly attracts tourists from the country where the gambling business is banned. Based on the tourism development strategy of Adjara, it becomes important to intensify the diversification of tourism and to promote the areas that the region really has potential for. In particular, it is adventure tourism, rural tourism, eco-tourism and mountain-skiing tourism. At this stage, it is necessary to select appropriate locations for adventure tourism, develop product concepts and create appropriate tourism infrastructure, in order to stimulate the business sector to be interested in the development of rural adventure tourism. Adventure tourism requires both physical and mental involvement from the tourist and at the same time requires from the stakeholders the sustainable development of tourism, protection of biodiversity, conservation of cultural resources and the creation and management of relevant tourism products. Adventure tourism as part of active tourism is well developed in connection with rural tourism and eco-tourism.

1 Nargiz Phalavandishvili e-mail: phalavandishvili.nargiz@bsu.edu.ge

2 Natalia Robitashvili e-mail: nato.robitashvili@bsu.edu.ge

3 Ekaterine Bakhtadze e-mail: bakhtadze.ekaterine@bsu.edu.ge 
Based on the above-mentioned, our research aims to determine the current level of development of adventure tourism and further perspectives, besides finding out the weak links in the existing value chain that prevent the creation of a competitive tourism product. In addition, all the services included in the value chain should be determined, and the appropriate calculation should be made to determine the average value. Quantitative and qualitative research methods are used in the research.

\section{Research results and discussion}

Adventure tourism is one of the fastest-growing categories of tourism, represented in virtually every country at all levels of economic development. The priority of this direction of tourism is that the formation of adventure tourism product is accompanied by the involvement of ecological, cultural and economic values. The Adventure Travel Trade Association (ATTA) explains that adventure travel should include at least two of these three elements (World Tourism Organization report, Global Report on Adventure Tourism, p. 10): Physical activity, natural environment and cultural involvement. Adventure tourism generally attracts both international and domestic tourists. Adventure tourism based on its activities, the number of which is 34 based on the materials of the World Tourism Organization, includes three types of products: soft (Archeological expedition, Backpacking, Birdwatching, Eco-tourism, Educational programs, Environmentally sustainable activities, Fishing/fly-fishing, Hiking, Horseback riding, Hunting, Kayaking/sea/whitewater, Orienteering, Rafting, Safaris, Sailing, Scuba Diving, Safaris, Snorkeling, Skiing/snowboarding, Volunteer Tourism, Research expeditions, Surfing), hard (Climbing (mountain/rock/ice), Trekking) and other (Attending local festival/fairs, Cultural activities, Getting to know the locals, Walking tours, Visiting friends/family, Visiting historical sites) (UNWTO., 2014).

From the activities of adventure tourism, in the region of Adjara, we can find archeological expeditions, walking tours, bird watching, cultural activities in the countryside, educational programs, hunting, horseback riding, rafting, skiing, visiting historical sites. As we can see we have mainly developed soft and other activities. The development of hard activities is hindered by the low professionalism, experience of instructors, and lack of appropriate infrastructure.

Adventure tourism undoubtedly provides sustainable rural development that can bring some benefits at different social levels, it can create jobs based on the traditional knowledge and experience of the locals.

The demand for adventure tourism is influenced by such factors as:

- Tour cost

- Price of related services, such as logistics costs

- Target market revenues

These factors should be taken into account by the business when forming competitive tourism products. (Koscak M., O'Rourke T., 2017).

Proper branding of the region, creation of a special online platform, formation of specific activities as a tourist product and their corresponding promotion are important for positioning locations in terms of adventure tourism. Along with adventure activities, it is no less important to create customized accommodation for the target customer, creating campsites, taking into account eco-tourism trends, in particular healthy, organic food, using alternative energy sources, training relevant staff and purchasing equipment. It is important to take into account the experience of foreign colleagues, to invite them for special infrastructure formation and staff training. In modern times, eco and adventure tourism often intersect. Ecotourism with an active component allows tourists to be classified according to lifestyle and age (Metreveli M., 2012). 
The Adventure Travel Trade Association (ATTA) determines the ranking of countries in terms of the development of adventure tourism:

Table 1

Top ten countries for adventure travel, 2020

\section{Source: ATDI, 2020}

\begin{tabular}{|c|c|c|}
\hline$\#$ & Developed countries & Developing countries \\
\hline 1 & Island & Czech Republic \\
\hline 2 & Switzerland & Chile \\
\hline 3 & New Zealand & Slovak Republic \\
\hline 4 & Germany & Slovenia \\
\hline 5 & Norway & Israel \\
\hline 6 & Finland & Estonia \\
\hline 7 & Sweden & Poland \\
\hline 8 & Canada & Bulgaria \\
\hline 9 & Australia & Romania \\
\hline 10 & Denmark & Costa Rica \\
\hline
\end{tabular}

In the ranking process for countries, the organization pays attention to various criteria, namely: Supporting Sustainable Development, Government Policy, Security \& Protection, Health, Natural Resources, Cultural Resources, Adventure Resources, Entrepreneurship, Tourism Infrastructure, Image and Humanity.

To assess the current state of adventure tourism in Adjara and the opportunities and threats for its further development, qualitative information was collected using in-depth interviews with specialists in the field, mainly representatives of the department of tourism and resorts of Ajara Autonomous Republic and tourist agencies offering adventure tourism activities. The information received was the basis for compiling the following table: 
Potential of Adventure tourism by locations in Ajara

\begin{tabular}{|c|c|c|}
\hline Locations & $\begin{array}{l}\text { Tourist infrastructure } \\
\text { and adventure activities }\end{array}$ & $\begin{array}{l}\text { Development } \\
\text { stage }\end{array}$ \\
\hline $\begin{array}{l}\text { Chirukhi Mountain } \\
\text { (Shuakhevi Municipality) }\end{array}$ & $\begin{array}{l}\text { It is planned to arrange the longest zip line in Europe } \\
\text { ( } 1752 \text { meters), which will be two-lane. With a zip } \\
\text { line, Chirukhi becomes the centre of attraction, this, } \\
\text { in turn, will lead to the arrangement of appropriate } \\
\text { tourism infrastructure - upper and lower stations, } \\
\text { food facilities, information centre, resting place. }\end{array}$ & Project \\
\hline $\begin{array}{l}\text { Chvana valley } \\
\text { (Shuakhevi Municipality) }\end{array}$ & $\begin{array}{l}\text { Chvani valley is loaded with historical and cultural } \\
\text { monuments. Chvani valley has great potential for the } \\
\text { development of adventure and extreme tourism. It } \\
\text { will be possible to climb the cliffs, enjoy mountain } \\
\text { biking, horseback riding and more. An integral part } \\
\text { of extreme tourism is the placement of capsules } \\
\text { hanging on a rock. Chvana valley is involved in a very } \\
\text { interesting route, the length of which is } 88 \mathrm{~km} \text { : } \\
\text { Kintrishri Protected Area (Kobuleti Municipality) - } \\
\text { Gomi Mountain (Guria Region) - Jvari Mindori - } \\
\text { Khabelashvili Bridge }\end{array}$ & Project \\
\hline $\begin{array}{l}\text { Machakhela } \\
\text { (Khelvachauri Municipality) }\end{array}$ & $\begin{array}{l}\text { The tourism infrastructure of Machakhela Valley } \\
\text { mainly serves the development of rural tourism, at } \\
\text { the same time includes the adventure activities of } \\
\text { rural tourism. The concept of Machakhela Valley } \\
\text { Ethno Village aims to interact with the local } \\
\text { population. Machakhela Mountain is planned to be } \\
\text { granted the status of a protected landscape }\end{array}$ & $\begin{array}{l}\text { Tours are } \\
\text { carried out }\end{array}$ \\
\hline $\begin{array}{l}\text { Goderdzi, Beshumi and Green } \\
\text { Lake (Khulo Municipality) }\end{array}$ & $\begin{array}{l}\text { Goderdzi is an emerging tourist location, appealing in } \\
\text { all four seasons of the year. Here all the conditions } \\
\text { are created to develop a mountain-ski resort, at the } \\
\text { same time an alpine botanical garden was arranged. } \\
\text { Beshumi is the best resort to build the necessary } \\
\text { infrastructure for camping. Tourist infrastructure for } \\
\text { hiking enthusiasts is arranged around the Green } \\
\text { Lake. }\end{array}$ & $\begin{array}{l}\text { Tours are } \\
\text { carried out }\end{array}$ \\
\hline $\begin{array}{l}\text { Mtirala National Park (Kobuleti } \\
\text { Municipality) }\end{array}$ & $\begin{array}{l}\text { Mtirala National Park is rich in flora and fauna, with } \\
\text { one- and two-day tourist routes. The paths are } \\
\text { marked and landscaped. Arranged for picnic and } \\
\text { camping places, the national park offers hiking, } \\
\text { horseback riding, science and eco-tours. Zipline is } \\
\text { arranged in Mtirala National Park. }\end{array}$ & $\begin{array}{l}\text { Tours are } \\
\text { carried out }\end{array}$ \\
\hline $\begin{array}{l}\text { Sakhalvasho and Chaisubani, } \\
\text { (Kobuleti Municipality) }\end{array}$ & $\begin{array}{l}\text { The best place for those who share information about } \\
\text { the ecology and migration of birds. There are } \\
\text { platforms for bird watching. }\end{array}$ & $\begin{array}{l}\text { Tours are } \\
\text { carried out }\end{array}$ \\
\hline $\begin{array}{l}\text { Khikhani Fortress, } \\
\text { (Khulo Municipality) }\end{array}$ & $\begin{array}{l}\text { The castle dates back to the X-XIII centuries. At this } \\
\text { stage, a path to the castle is made, which is a real } \\
\text { discovery for tourists interested in hiking and } \\
\text { historical monuments. }\end{array}$ & $\begin{array}{l}\text { Tours are } \\
\text { carried out }\end{array}$ \\
\hline $\begin{array}{l}\text { Uchkho Canyon, } \\
\text { (Khulo Municipality) }\end{array}$ & $\begin{array}{l}\text { The beautiful one-and-a-half-kilometer canyon } \\
\text { allows hikers to access the } 12 \text {-cascading waterfall } \\
\text { with ropes. Uchko is the first canyoning tourist route } \\
\text { in Adjara, which makes the region's tourist products } \\
\text { even more diverse. }\end{array}$ & Project \\
\hline $\begin{array}{l}\text { Kaviani Fortress - to Dandalo, } \\
\text { Shuakhevi - Keda Municipality }\end{array}$ & Arranging a bicycle path for mountain biking lovers. & Project \\
\hline $\begin{array}{l}\text { Ghorjomi valley - resort } \\
\text { Bakhmaro } \\
\text { (Khulo municipality / } \\
\text { Guria region) }\end{array}$ & Mount Leknari-Bakhmaro: Route for hiking & $\begin{array}{l}\text { Tours are } \\
\text { carried out }\end{array}$ \\
\hline
\end{tabular}

Source: Author's created based on the results of the survey 
A value chain is a network that connects value-creating actions, starting with the supplier including actions that include manufacturing, product service and marketing, ending with product delivery to the final buyer.

The concept of "value chain" was first introduced by Michael Porter. Porter and Millar (1985) state: "The value a company creates is measured by the amount that buyers are willing to pay for a product or service". A company reaches profitability when its margin value is positive, meaning value created exceeds arising costs associated (Porter and Millar, 1985). According to Porter and Millar, a company's value chain is a 'system of interdependent activities, which are connected by linkages. He viewed it in the context of adding value to the product in a sectoral context, in particular, it indicated that at each stage of processing, from the extraction of the raw material to its consumption by the end-user, a certain value is added to the product, in other words, the value chain in the sector reflects the whole process of transformation in individual sectors, starting from the extraction of primary raw materials, ending with the delivery of goods to the final consumer and consumption. (Belgen M., Elif A., 2014)

The researchers have introduced the following definitions of 'value chain of tourist products.

- A typical travel product value chain has four components: travel service provider, tour operator, travel agent and customers (M. Kaukal, W. Hopken, H. Werthner, 2000).

- The value chain (health tourism) is viewed as a sequence of links: the preceding subsystem (travel companies, incentive companies, health insurance); transportation (auto, air, rail transport); accommodation (hotels, resorts, boarding houses, campsites); public catering (restaurants, bars, clubs, canteens, cafes); health-improving activity (fitness, sports, beach, relaxation, healthy eating) (K. Weiermair, S. Steinhauser, 2003).

- The process of adding value to a tourism product by participants in the tourism industry and providing it to the client in places visited by tourists (OECD, 2008).

- The value chain is divided into five production activities (or segments): accommodation, public catering, the performance of travel agencies and tour operators, transport and trade. There is a thesis that within each segment, several different supply chains can be distinguished (R. Denman, J. Denman, 2009).

- The tourism product supply chain (TSC) is defined as a network of tourism organizations of various activities that create value from different components of tourism products or services in a total tourism product at a specific tourism destination, includes a wide range of participants in both the private and public sectors (X. Zhang, H. Song, G. Q. Huang, 2009).

The value-creating activities occur at two levels, namely: within the industry in which a company exists (industry value chain) and within a company itself (firm's value chain). Creation of value is a function of the ability to deliver high performance on the benefits that are important to the customer. Value chain analysis requires the "mapping of the market" to track and analyse the contribution of the different chain actors and the relationships among themselves. An understanding of the interactions within a value chain helps identify the factors that influence how well or how badly the chain works. The resulting market map defines the value chain actors, the enabling environment and the service providers. The enabling environment includes critical factors that create the operating conditions within which the value chain operates, such as infrastructure, policies, and regulations, as well as institutions and processes that shape the market ecosystem. Service providers, on the other hand, include business or extension services that provide support to the value chain, such as providers of market information, financial services, transport services, R\&D facilities, and accreditation services. Industry level value chain analysis is an effective way to examine the interaction among different players in a given industry. Value chain analysis (VCA) includes 
both qualitative and quantitative approaches. Observation, semi-structured interviews, focus group meetings, and questionnaires are recommended to build up an understanding of the various chain players and how they interact with one another. (Zamora E., 2016)

In the report, 'Aid for trade and value chains in tourism' (Marion Jansen, OECD/UNWTO/WTO, 2013) the author presents the value chain in tourism. Along with the key links that create a value chain, the paper discusses the sectors indirectly related to this process and the services created by them. According to the model presented in the report, which we think perfectly reflects the process of creating a value chain in tourism, value creation begins before the visitor arrives.

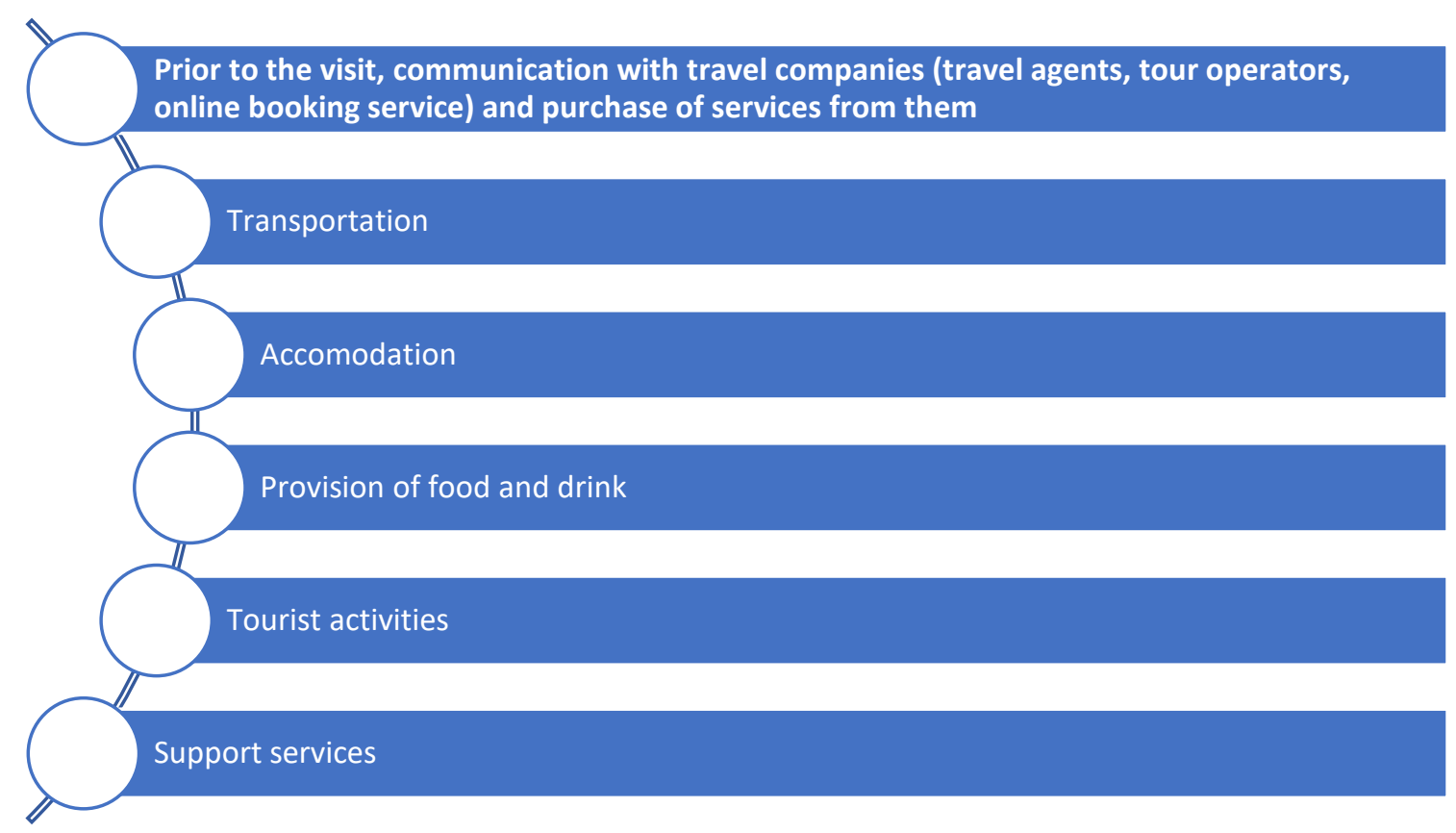

Source: WTO, 2013

Fig. 1. Value chain links to tourism

- The first line is related to communication with travel companies (tour agencies, tour operators, online booking services) and the purchase of services from them;

- Line II is the transportation of the visitor;

- Line III - Accommodation;

- Line IV - Provision of food and drink;

- Line $\mathrm{V}$ - the use of tourist assets on the tourist destination, which in turn can be divided into cultural and natural assets, followed by recreation, excursions and tours;

- Line VI - Support services (security, internet, financial services, trade services etc.).

Both public and private organizations supporting tourism development are indirectly involved in the value chain process in tourism. The model presented in this report generally reflects the process of creating a value chain in the tourism sector, although the value chain model is usually created at the level of specific tourism products.

As a result, the adventure tourism product value chain includes 6 main stages.

1) creating and developing a product concept. The main initiators of creating the concept of adventure product in Adjara are governmental organizations, they create route routes, mark them, create appropriate infrastructure and interest tour operators and tour bureaus with relevant tours. 
2) Promotion and sale. Adventure tours are promoted by the Department of Tourism and Corrections through social media, websites and print ads in information centres. Special brochures and maps have been prepared.

3) Accommodation and meals.

4) Transportation to the destination.

5) Support tourist services: Guide, instructor services, and more.

6) International transportation.

Thus, the main participants/players in the value chain according to Wilson Sh., Sagewan-Alli I. (2014) are:

- users: Domestic and international tourists;

- suppliers: These include government agencies - the Department of Tourism and the Agency and Private, Protected Areas: Tour operators and tour agents;

- organizations involved in the promotion;

- transportation Organizations / Tourist Guides / Excursion Bureaus.

As the research showed, most of the locations have accommodation and food facilities, however, the low quality of service remains a significant problem in this area. Based on the value chain analysis, it is possible to visualize the general structure of visitor costs by considering the elements of tourism services.

Based on the study of the prices of the tourist services included in the existing adventure tours, we tried to create a general value chain for the formation of the adventure product. Each line shows what the tourist spends.

Table 3

Tourist Expenditures by the components of adventure tourist service

\begin{tabular}{|l|c|c|}
\hline \multicolumn{1}{|c|}{$\begin{array}{c}\text { Adventure tourism service } \\
\text { components }\end{array}$} & $\begin{array}{c}\text { Cost per } \\
\text { person per day (euro) }\end{array}$ & Cost in \% \\
\hline $\begin{array}{l}\text { Transportation from Batumi to } \\
\text { the destination }\end{array}$ & 5 & 10 \\
\hline Accommodation & 12.5 & 25 \\
\hline Food & 10 & 20 \\
\hline Guide service & 10 & 20 \\
\hline Shopping, souvenirs & 7.5 & 15 \\
\hline Taxes & 5 & 10 \\
\hline Total: & 50 & 100 \\
\hline
\end{tabular}

Source: author's created based on the results of the survey

The value chain analysis of adventure tourist product enables us to draw the following recommendations and conclusions.

1) The role of state investments in the diversification of tourism products is important, in particular, the arrangement of relevant tourism infrastructure and business support.

2) It is important to create specialized locations for different types of adventure tourism activities based on the tourism-recreational potential of the Adjara region.

3) In the process of forming adventure products, more attention should be paid to staff training in terms of providing relevant services. 
4) Based on the results of the survey, the food line appeared to be a weak line in the value chain, because it is important for tourists to find a healthy, local product, and in general, it is necessary to increase the quality of service in all lines.

5) Accommodation with the highest share in the structure at the expense of visitors is distinguished. Overall, the cost of the adventure tour is affordable for both international and domestic tourists, which is a contributing factor to the development of this type of tourism.

\section{Bibliography}

1. Adventure Travel Association. Retrieved:https://www.adventuretravelnews.com/atdi-2020-released-icelandand-czech-republic-score-top-marks-for-adventure-tourism-competitiveness-in-2020 Access: 24.03.2021.

2. Aid for Trade and Value Chains in Tourism. (2013) OECD/UNWTO/WTO pp.23-24

3. Belgen, M., Elif, A. (2014). A Value Chain Analysis of Turkish Tourism Sector. International journal of business and Management studies. pp. 500-501

4. Denman R., Denman J. (2009). Tourism and Poverty Alleviation: Practical Steps for Destinations // SNV \& UNWTO. pp.19

5. Department of tourism and resorts of Ajara Autonomous Republic. Retrieved: http://gobatumi.com/en/type-oftourism Access: 24.03.2021.

6. Global Report on Adventure Tourism. (2014). The World Tourism Organization (UNWTO), pp.12-13

7. Kaukal, M., Hupken, W., Werthner, H. (2000). An Approach to Enable Interoperability in Electronic Tourism Markets. // Proceedings of the 8th European Conference on Information System. ECIS 2000. Retrieved: http://195.130.87.21:8080/dspace/bitstream/123456789/886/1/An\%20approach\%20to\%20enable\%20interop erability\%20in\%20electronic\%20tourism\%20.pdf Access: 24.03.2021.

8. Koscak M., O'Rourke T. Active \& Adventure Tourism in the Planning of Local Destination Management - with Case Studies from Slovenia and Scotland. Retrieved:

https://www.researchgate.net/publication/329897134_Active_adventure_tourism_in_the_planning_of_local_de stination_management_with_case_studies_from_Slovenia_and_Scotland pp.102-103 Access: 24.03.2021.

9. Metreveli, M., (2012). Environment and Ecotourism Management, Tbilisi, pp. 30-32

10. Porter, M. E. (1985). Competitive Advantage. New York: The Free Press, p. 150

11. Wilson, Sh., Sagewan-All,i I. (2014). Private Sector Promotion Through Value Chain and Cluster Strengthening in Cariform pp.46-47

12. Weiermair, K., Steinhauser, C (2003). New Tourism Clusters in the Field of Sports and Health; the Case of Alpine Wellness // 12-th International Tourism and Leisure Symposium Barcelona. April 2003 p. 12. Retrieved: http://citeseerx.ist.psu.edu/viewdoc/download;jsessionid=490D9EC5193A22ACB4168F0BEDC128EF?doi=10.1. 1.472.646\&rep $=$ rep1\&type $=$ pdf Access: 24.03.2021.

13. Zamora, E., (2016). Value Chain Analysis: A Brief Review. Asian Journal of Innovation and Policy 5 (2). pp. $118-119$

14. Zhang, X., Song, H., Huang, G. Q. (2009). Tourism Supply Chain Management: A New Research Agenda //Tourism Management. № 30. P. 8. Retrieved: http://ira.lib.polyu.edu.hk/bitstream/10397/1129/1/18TSCM.pdf Access: 24.03.2021. 